\title{
Comment for Counting Sepsis, an Imprecise but Improving Science
}

\author{
Zhong Jia*, Yue Zhou and Jie Ni \\ Hangzhou First People's Hospital, Nanjing Medical University Affiliated Hangzhou Hospital, China
}

Submission: December 16, 2017; Published: January 08, 2018

"Corresponding author: Zhong Jia, Department of Hepatopancreatobililiary Surgery, Huansha Road No. 261, Hangzhou First People's Hospital, Nanjing Medical University Affiliated Hangzhou Hospital, Hangzhou, Zhejiang 310006, China, Mobile phone: +86-13958114181; Fax:+86-057187914773; Email: jiazhong20058@hotmail.com

\section{Comment}

A major concern to us is the fact that, beside of the death caused by sepsis, obesity also a potential risk was devolved as patients with high-income seemed to be more likely developing severe sepsis. This is very attractive for and, to our point of view, has to be counted prior to ICD of sepsis [1]. This leads to the clinical pathway for sepsis if the patient really suffered from sepsis or "septicemia". The authors have to demonstrate how amounts of income powerfully associated outcomes of sepsis or income indeed collaborate with potential risks such as high lipid or high glycemia.

Another major concern is the clinical management of the sepsis. After patients' admission to hospital with severe sepsis it is recommended to perform top antibiotic to control or protect potential organ function. In the current challenges from sepsis, no ICD for sepsis was conducted and an international standardized sample of ICD displayed. Again, this is very instructive procedure. In addition, identifying sepsis testing should outweigh clinical experience. Still, controversial remains. Sometimes, timely surgical drainage for primary infectious foci is more important.

Although the sepsis is not easily explained in a comprehensible manner, ICD- sepsis in good order will be favorable for sepsis improvement on the horizon.

\section{Declaration}

All authors declare that they have no conflict of interests on the manuscript.

\section{References}

1. Rudd KE, Delaney A, Finfer S (2017) Counting sepsis, an imprecise but improving science. JAMA 318(13): 1228-1229.

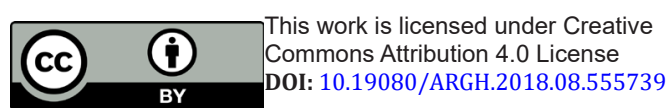

Your next submission with JuniperPublishers
will reach you the below assets
- Quality Editorial service
- Swift Peer Review
- Reprints availability
- E-prints Service
- Manuscript Podcast for convenient understanding
- Global attainment for your research
- Manuscript accessibility in different formats
( Pdf, E-pub, Full Text, audio)
- Unceasing customer service
Track the below URL for one-step submission
https://juniperpublishers.com/online-submission.php

